\title{
The safety and efficacy of aspirin intake in photoselective vaporization laser treatment of benign prostate hyperplasia [Corrigendum]
}

\author{
Shao IH, Hou CP, Chen SM, Chen CL, Lin YH, Chang PL, \\ Tsui KH. The safety and efficacy of aspirin intake in photose- \\ lective vaporization laser treatment of benign prostate hyper- \\ plasia. Clinical Interventions in Aging. 2013, 8:265-269. \\ The authors' affiliations are incorrectly noted as being in \\ Taiwan, People's Republic of China. It should be Taiwan, \\ Republic of China.
}

\section{Publish your work in this journal}

Clinical Interventions in Aging is an international, peer-reviewed journal focusing on evidence-based reports on the value or lack thereof of treatments intended to prevent or delay the onset of maladaptive correlates of aging in human beings. This journal is indexed on PubMed Central, MedLine, the American Chemical Society's 'Chemical Abstracts
Service' (CAS), Scopus and the Elsevier Bibliographic databases. The manuscript management system is completely online and includes a very quick and fair peer-review system, which is all easy to use. Visit http://www.dovepress.com/testimonials.php to read real quotes from published authors. 